\title{
Fluoroscopic caudal epidural injections in managing chronic axial low back pain without disc herniation, radiculitis, or facet joint pain
}

This article was published in the following Dove Press journal:

Journal of Pain Research

II October 2012

Number of times this article has been viewed

\author{
Laxmaiah Manchikanti ${ }^{1,2}$ \\ Kimberly A Cash' \\ Carla D McManus' \\ Vidyasagar Pampati'
}

'Pain Management Center of Paducah, Paducah, ${ }^{2}$ Department of Anesthesiology and Perioperative Medicine, University of Louisville, Louisville, KY, USA
Correspondence: Laxmaiah Manchikanti 283I Lone Oak Road, Paducah, KY 42003, USA

Tel +I 2705548373 ext I0 I

Fax + I 2705548987

Email drIm@thepainmd.com
Background: Chronic low back pain without disc herniation is common. Various modalities of treatments are utilized in managing this condition, including epidural injections. However, there is continued debate on the effectiveness, indications, and medical necessity of any treatment modality utilized for managing axial or discogenic pain, including epidural injections.

Methods: A randomized, double-blind, actively controlled trial was conducted. The objective was to evaluate the ability to assess the effectiveness of caudal epidural injections of local anesthetic with or without steroids for managing chronic low back pain not caused by disc herniation, radiculitis, facet joints, or sacroiliac joints. A total of 120 patients were randomized to two groups; one group did not receive steroids (group 1) and the other group did (group 2). There were 60 patients in each group. The primary outcome measure was at least $50 \%$ improvement in Numeric Rating Scale and Oswestry Disability Index. Secondary outcome measures were employment status and opioid intake. These measures were assessed at 3, 6, 12, 18, and 24 months after treatment.

Results: Significant pain relief and functional status improvement (primary outcome) defined as a $50 \%$ or more reduction in scores from baseline, were observed in $54 \%$ of patients in group 1 and $60 \%$ of patients in group 2 at 24 months. In contrast, $84 \%$ of patients in group 1 and $73 \%$ in group 2 saw significant pain relief and functional status improvement in the successful groups at 24 months.

Conclusion: Caudal epidural injections of local anesthetic with or without steroids are effective in patients with chronic axial low back pain of discogenic origin without facet joint pain, disc herniation, and/or radiculitis.

Keywords: chronic axial low back pain, discogenic pain, disc herniation, caudal epidural injections

\section{Introduction}

Discogenic low back pain is nonradicular and occurs in the absence of spinal deformity, instability, and signs of nerve root irritation, and arises from the disc itself. Its mechanism of production is uncertain. ${ }^{1-3}$ In the absence of evidence of disc herniation, it may be impossible to localize a painful disc from the symptoms and signs elicited on physical examination. Axial low back pain without radiculitis is similar to the pain produced by zygapophyseal joints, the sacroiliac joint, or a musculoligamentous origin of pain..$^{4-14}$ In fact, a year after the description of lumbar disc herniation as causation of low back and lower extremity pain by Mixter and Barr, ${ }^{15}$ Mixter and Ayers ${ }^{16}$ showed that radicular pain can occur without disc herniation. Multiple studies have found that lumbar disc herniation is not the major cause of low back pain, and that discogenic 
pain caused by annular disruption is one of the most important causes. ${ }^{17,18}$ The complex mechanism of discogenic pain has been well described, with chemical nociception leading to low back pain without disc herniation, along with internal disc disruption. ${ }^{1,4,7,8,19-24}$ The research in animals has shown that upregulation of various pain-regulated molecules, such as calcitonin gene-related peptide and substance $\mathrm{P}$, in the dorsal root ganglion neurons innervates degenerated intervertebral discs. ${ }^{25,26}$ Nonspecific low back pain constitutes $80 \%-90 \%$ of low back pain without identifiable causes, with a large proportion having chronic axial low back pain secondary to progressive degenerative disc disease. ${ }^{1,5,6,8,27,28}$ Further, the majority of patients with axial low back pain improve with conservative management, and various types of interventions described provide highly variable and mostly poor outcomes. ${ }^{28-40}$

Even though not well known, and continually debated, epidural injections are one of the most common interventions performed for managing axial low back pain without disc herniation..$^{37,38,40-51}$ Despite emerging evidence, $37,38,45-61$ epidural injections in general, and their role in managing axial or discogenic low back pain in particular, have been questioned. ${ }^{37,38,40,42,43,45,62-64}$ However, in evaluating axial low back pain, some studies have failed to rule out facet joint, sacroiliac joint, or other sources of pain prior to treating with epidural injections.

This study sought to evaluate the role of caudal epidural injections in patients with chronic low back pain without disc herniation, radiculitis, facet joint pain, sacroiliac joint pain, or other sources of chronic low back pain who were shown to be negative for facet joint and sacroiliac joint pain by controlled comparative local anesthetic blocks; myofascial pain was ruled out by physical examination. This report is the final report of 120 patients at 2-year follow-up, after a previous preliminary publication, ${ }^{65}$ and one-year follow-up report. $^{37}$

\section{Materials and methods}

This randomized, double-blind, controlled trial was conducted in the US in a private interventional pain practice and specialty referral center based on Consolidated Standards of Reporting Trials guidelines. ${ }^{66}$ The protocol was approved by the local institutional review board, and registered with the US Clinical Trial Registry (NCT00370799). The study was conducted within the principles of the Declaration of Helsinki, with informed consent approved by the institutional review board and signed by all participants. This study was conducted with the internal resources of the practice without any external funding either from industry or elsewhere.
All participants received the protocol and informed consent form approved by the institutional review board, detailing all aspects of the study and the withdrawal process.

\section{Interventions}

Participants were recruited from new patients presenting for interventional pain management. A total of 120 participants were assigned to one of two groups, with group 1 patients receiving caudal epidural injections with local anesthetic (lidocaine $0.5 \%, 10 \mathrm{~mL}$ ) and group 2 patients received caudal epidural injections with $9 \mathrm{~mL}$ of $0.5 \%$ lidocaine mixed with $1 \mathrm{~mL}$ of steroid (either brand name or nonparticulate betamethasone [6 mg] or methylprednisolone [40 mg]). Each injection was flushed with a $2 \mathrm{~mL}$ solution of $0.9 \%$ sodium chloride solution.

\section{Pre-enrollment evaluation}

Controlled comparative local anesthetic blocks were performed during a pre-enrollment evaluation to exclude facet joint or sacroiliac joint pain. Patient demographic data, medical and surgical history with coexisting disease(s), radiologic investigations, physical examination, pain rating scores using the Numeric Rating Scale (NRS), functional status assessment by Oswestry Disability Index 2.0 (ODI), work status, and opioid intake were collected.

\section{Inclusion criteria}

Participants in this trial met all inclusion criteria including: no evidence of disc herniation and a negative diagnosis of lumbar facet joint pain and sacroiliac joint pain by means of controlled local anesthetic blocks; being at least 18 years of age; a history of chronic function-limiting low back pain of at least 6 months' duration; competent to understand the study protocol and provide voluntary, written, informed consent as well as participate in outcome measurements; and failure to improve substantially with conservative management, including but not limited to physical therapy, chiropractic manipulation, exercises, drug therapy, and bedrest.

\section{Exclusion criteria}

Patients with facet joint pain; previous lumbar surgery; uncontrolled or unstable opioid use; uncontrolled psychiatric disorders; uncontrolled medical illness, either acute or chronic; and any other conditions that could interfere with the interpretation of outcome assessments, including pregnant or lactating women, and participants with a history or potential for an adverse reaction or reactions to either local anesthetics, steroids, or both, were excluded. 


\section{Description of interventions}

Controlled comparative local anesthetic facet joint nerve blocks were performed on all participants. First, diagnostic facet joint nerve blocks were conducted with $0.5 \mathrm{~mL}$ of $1 \%$ lidocaine. Then, on separate occasions, blockade of facet joint nerves was conducted with $0.25 \%$ bupivacaine. ${ }^{4,67}$ A response was considered negative if pain relief lasted less than 2 hours following lidocaine injection, and lasted less than 3 hours or less than the duration of relief with lidocaine when bupivacaine was used. Diagnostic sacroiliac joint blocks were performed utilizing $2 \mathrm{~mL}$ of $1 \%$ lidocaine or $0.25 \%$ bupivacaine.

A physician performed the caudal epidural procedures in a sterile operating room located in an ambulatory surgery setting, using fluoroscopy. Participants were in the prone position and were monitored appropriately with intravenous access. Midazolam and/or fentanyl were administered if indicated. After confirmation of entry into the epidural space by injection of nonionic contrast medium, the assigned solution was injected.

\section{Additional interventions}

Treatments were given to participants as assigned. Upon request, or if an emergency situation arose, a patient was unblinded. Based on a patient's response to prior caudal epidural injections and improvement in physical and functional status, repeat caudal epidural injections were performed when increased levels of pain were reported with deteriorating relief below $50 \%$. However, nonresponsive participants were treated with conservative management and were followed without further epidural injections with medical management, without unblinding. Conservative management with appropriate drug therapy and a therapeutic exercise program were continued as needed, along with work. There were no other interventions. The objective of this study was to investigate the effectiveness of caudal epidural injections with or without steroids in patients with chronic axial low back pain not caused by disc herniation, radiculitis, or facet joint pain.

\section{Outcomes}

Multiple outcome measures were used, including NRS pain scale (0-10), ODI (0-50) for functional assessment, employment status, and morphine-equivalent opioid use at $3,6,12,18$, and 24 months. The accuracy of the NRS and ODI has been established..$^{68} \mathrm{~A}$ primary outcome measure of significant pain relief and improvement with $50 \%$ or more reduction in NRS from baseline and 50\% reduction in the ODI was utilized. ${ }^{38,48-57,69-71}$ Categories for employment and work status included employable, retired, over age 65 years, or housewife with no desire to work outside the home. Participants who, because of pain, were unemployed, on sick leave but employed, or laid off were considered as employable. Thus, the criteria for work status were based on the type of work status if they were employable or not. Morphine equivalency was utilized to evaluate opioid usage. $^{72}$

\section{Sample size and randomization}

The sample size was calculated based on significant pain relief. Considering a 0.05 two-sided significance level, a power of $80 \%$, and an allocation ratio of $1: 1,55$ participants in each group were estimated to be necessary. ${ }^{73}$ Allowing for a $10 \%$ attrition/noncompliance rate, 60 participants were required. Each group was randomly assigned 60 participants. Computer-generated random allocation sequence by simple randomization was utilized. The nurse coordinator, without knowledge of the patient, physician, or other personnel, completed the randomization and drug preparation. All patients meeting the inclusion criteria were invited to participate. They were enrolled and assigned to a group by a nurse coordinator. Group assignments were blinded to participants and the interventional investigators. Study participants were mixed with routine treatment patients.

\section{Statistical methods}

Data analyses were carried out using the Statistical Package for Social Sciences version 9.01 (SPSS Inc, Chicago, IL). For categorical and continuous data comparison, Chi-squared statistics, Fisher's Exact test, one-way analysis of variance, $t$-tests, and paired $t$-tests were the statistical analyses used. Because the outcome measures of the participants were measured at six points in time, repeated-measures analysis of variance was performed with the post hoc analysis. A $P$ value of less than 0.05 was considered to be statistically significant. Initially, three subgroups of participants receiving steroids in group 2 were analyzed for any differences. If no significant differences were observed, the results were presented as a single group. A sensitivity analysis with changes in the NRS was performed utilizing the last followup score, best case scenario, and worst case scenario if there were no significant differences; the intention-to-treat analysis by last follow-up visit was used.

\section{Results}

Figure 1 illustrates the participant flow. The enrollment period lasted from January 2007 to August 2008. 


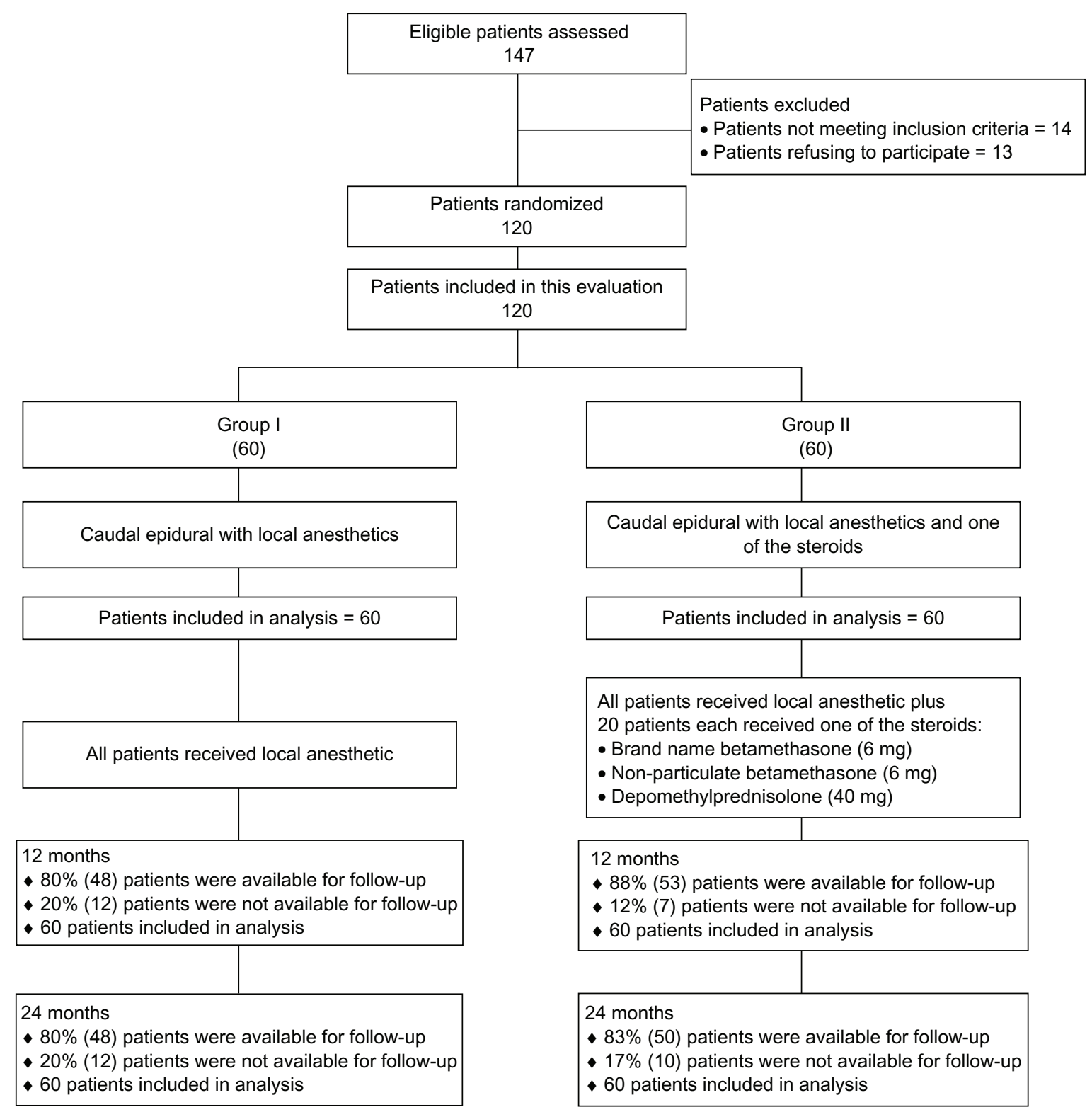

Figure I Schematic presentation of participant flow.

Baseline characteristics are illustrated in Table 1. There were significant differences in relation to distribution of gender, age, and mean height. However, even though these are significant, they are not expected to be the cause of any differences. The proportion of women was higher in group 1 compared with group 2. Patients in group 1 were slightly older than the ones in group 2; in addition, mean height was slightly higher in group 2 . Intention-to-treat analysis was carried out by last follow-up data, as there were no differences noted with sensitivity analysis.

The epidural injections were considered successful if the patient experienced at least 3 weeks of pain relief with the initial two procedures. A failure was any other result.
Table 2 illustrates these results. Over the 2-year study period, group 1 had mean overall pain relief of $46.7 \pm 38.3$ weeks, and group 2 had $58.3 \pm 38.0$ weeks. However, when participants were separated into successful and failed groups, the successful participants' total number of procedures per year was $5.7 \pm 2.3$ in group 1 and $6.4 \pm 2.0$ in group 2 , with relief of $69.7 \pm 28.8$ weeks in group 1 and $76.1 \pm 27.4$ weeks in group 2; 37 of 60 participants (62\%) in group 1 and 41 of 60 participants (68\%) in group 2 had improvement.

\section{Outcomes}

Table 3 presents the results of repeated-measures analysis. There were significant differences in participants' average 
Table I Baseline demographic characteristics

\begin{tabular}{|c|c|c|c|}
\hline & $\begin{array}{l}\text { Group I } \\
(n=60)\end{array}$ & $\begin{array}{l}\text { Group } 2 \\
(n=60)\end{array}$ & $P$ value \\
\hline \multicolumn{4}{|l|}{ Gender } \\
\hline Male & $22 \%(13)$ & $37 \%(22)$ & 0.071 \\
\hline Female & $78 \%(47)$ & $63 \%(38)$ & \\
\hline \multicolumn{4}{|l|}{ Age, years } \\
\hline Mean \pm SD & $48.5 \pm 15.3$ & $43.9 \pm 13.1$ & 0.08 \\
\hline \multicolumn{4}{|l|}{ Weight (lbs) } \\
\hline Mean \pm SD & $189.5 \pm 59.6$ & $|77| \pm 42.5$. & 0.190 \\
\hline \multicolumn{4}{|l|}{ Height (inches) } \\
\hline Mean \pm SD & $64.8 \pm 3.7$ & $66.3 \pm 3.6$ & 0.025 \\
\hline \multicolumn{4}{|c|}{ Duration of pain (months) } \\
\hline Mean \pm SD & $100 \pm 87.0$ & $92 \pm 85.4$ & 0.611 \\
\hline \multicolumn{4}{|l|}{ Onset of pain } \\
\hline Gradual & $70 \%(42)$ & $60 \%(36)$ & 0.339 \\
\hline Injury & $30 \%(18)$ & $40 \%(24)$ & \\
\hline \multicolumn{4}{|c|}{ Low back pain distribution } \\
\hline Bilateral & $83 \%(50)$ & $83 \%(50)$ & 1.000 \\
\hline Left or right & $17 \%(10)$ & $17 \%(10)$ & \\
\hline \multicolumn{4}{|c|}{ Numeric Rating Score } \\
\hline Mean \pm SD & $8.0 \pm 0.9$ & $7.9 \pm 1.0$ & 0.374 \\
\hline \multicolumn{4}{|c|}{ Oswestry Disability Index } \\
\hline Mean \pm SD & $28.3 \pm 4.92$ & $28.4 \pm 4.67$ & 0.939 \\
\hline
\end{tabular}

Abbreviation: SD, standard deviation.

pain scores within-group by time $(P<0.0001)$, and no significant differences between the two groups $(P=0.525)$. In the ODI for functional status, there were significant differences in summary scores within-group by time $(P=0.001)$ and no significant differences between two groups $(P=0.209)$. Paired-samples $t$-test analysis indicates that mean differences at baseline and the other five time points within the group were significant at the 0.05 level. Figure 2 illustrates the proportion of participants with a significant change in pain and function. Employment characteristics are shown in Table 4. Employment increased from a baseline of $62.5 \%$ in group 1 and $60 \%$ in group 2 to $100 \%$ in group 1 and $95 \%$ in group 2 .
Opioid intake is illustrated in Table 5, showing no significant differences. Table 6 shows no significant weight change in either group. None of the patients reported significant adverse events during the study period.

\section{Discussion}

Evaluation of a 2-year follow-up with 120 participants showed significant pain relief and improvement of functional status in a select group of patients, who were judged to be successful at $84 \%$ in group 1 and $73 \%$ in group 2 . However, the results were significant even with inclusion of all participants, with successful outcome with $54 \%$ in group 1 and $60 \%$ in group 2 at the end of 2 years. The total number of procedures in the successful category was $5.7 \pm 2.3$ in group 1 and $6.4 \pm 2.0$ in group 2. Further, in the successful category, the total relief over the 2-year study period was for $69.7 \pm 28.8$ weeks in group 1 and $76.1 \pm 27.4$ weeks in group 2. There was no significant change in opioid intake. In reference to employment, all of the participants in group 1 and $95 \%$ in group 2 who were eligible for employment were employed at the end of 2 years. As expected, the failed group showed inconsistent and inadequate relief. Further, this study illustrates that relief is limited in the majority of patients; the mean relief was approximately 13 weeks after the first two procedures. Consequently, well selected patients may respond on a long-term basis, but only with judicious repeat therapy. There were no significant differences when a steroid was used or according to what type of steroid was used among the three types of steroids.

The literature is replete with multiple studies and systematic reviews of epidural injections; however, there is a paucity of literature and evidence for managing axial or discogenic pain. ${ }^{24,37,38,40-43,45-50}$ There has been only one randomized controlled tria ${ }^{37,65}$ and one nonrandomized study ${ }^{46}$ evaluating

Table 2 Therapeutic procedural characteristics with procedural frequency, average relief per procedure, and average total relief in weeks over a period of 2 years for back pain

\begin{tabular}{|c|c|c|c|c|c|c|}
\hline & \multicolumn{2}{|c|}{ Successful participants } & \multicolumn{2}{|c|}{ Failed participants } & \multicolumn{2}{|l|}{ Combined } \\
\hline & $\begin{array}{l}\text { Group I } \\
(n=37)\end{array}$ & $\begin{array}{l}\text { Group } 2 \\
(n=4 I)\end{array}$ & $\begin{array}{l}\text { Group I } \\
(n=23)\end{array}$ & $\begin{array}{l}\text { Group } 2 \\
(n=19)\end{array}$ & $\begin{array}{l}\text { Group I } \\
(n=60)\end{array}$ & $\begin{array}{l}\text { Group } 2 \\
(n=60)\end{array}$ \\
\hline Average number of procedures first year & $3.8^{\#} \pm 0.9$ & $4.3 \pm 0.9$ & $2.5 \pm 1.3$ & $3.1 \pm 1.6$ & $3.3^{\#} \pm 1.3$ & $3.9 \pm 1.3$ \\
\hline Average number of procedures over two years & $5.7 \pm 2.3$ & $6.4 \pm 2.0$ & $2.7 \pm 1.6$ & $3.6 \pm 2.4$ & $4.5^{\#} \pm 2.5$ & $5.5 \pm 2.5$ \\
\hline Average relief per procedure for initial & $9.6 \pm 6.5$ & $9.5 \pm 11.4$ & $1.9 \pm 2.1$ & $1.7 \pm 2.2$ & $6.9 \pm 6.5$ & $7.1 \pm 10.3$ \\
\hline \multicolumn{7}{|l|}{2 procedures in weeks } \\
\hline Average relief per procedure after initial & $13.8 \pm 6.8$ & $13.1 \pm 7.5$ & $7.2 \pm 5.6$ & $9.7 \pm 5.8$ & $13.0 \pm 7.0$ & $12.6 \pm 7.3$ \\
\hline \multicolumn{7}{|l|}{2 procedures } \\
\hline Average relief per procedure & $12.3 \pm 7.0$ & $12.0 \pm 9.0$ & $3.7 \pm 4.4$ & $5.6 \pm 5.9$ & $10.4 \pm 7.4$ & $10.6 \pm 8.9$ \\
\hline Average total relief first year (weeks) & $40.8 \pm 9.4$ & $43.1 \pm 10.2$ & $7.9 \pm 10.4$ & $12.9 \pm 13.9$ & $28.2 \pm 18.8$ & $33.5 \pm 18.2$ \\
\hline Average total relief over 2 years (weeks) & $69.7 \pm 28.8$ & $76.1 \pm 27.4$ & $9.6 \pm 16.0$ & $19.9 \pm 28.1$ & $46.7 \pm 38.3$ & $58.3 \pm 38.0$ \\
\hline
\end{tabular}

Notes: \#Indicates significant difference versus group $2(P<0.05)$; Successful participant, at least one week relief at first injection and $\geq 4$ weeks relief at second injection. 
Table 3 Comparison of numeric pain rating scale for pain and oswestry disability index score summaries at six time points

\begin{tabular}{|c|c|c|c|c|}
\hline \multirow[t]{3}{*}{ Time points } & \multicolumn{4}{|l|}{ Mean \pm SD } \\
\hline & \multicolumn{2}{|c|}{ Numeric pain rating scale } & \multicolumn{2}{|c|}{ Oswestry disability index } \\
\hline & Group I $(n=60)$ & Group $2(n=60)$ & Group I $(n=60)$ & Group $2(n=60)$ \\
\hline Baseline & $8.0 \pm 0.9$ & $7.9 \pm 1.0$ & $28.3 \pm 4.9$ & $28.4 \pm 4.7$ \\
\hline 3 months & $\begin{array}{l}4.2^{*} \pm 1.8 \\
(68 \%)\end{array}$ & $\begin{array}{l}3.6 * \pm 1.4 \\
(80 \%)\end{array}$ & $\begin{array}{l}16.3^{*} \pm 7.2 \\
(60 \%)\end{array}$ & $\begin{array}{l}14.5^{*} \pm 5.5 \\
(75 \%)\end{array}$ \\
\hline 6 months & $\begin{array}{l}4.1 * \pm 1.8 \\
(68 \%)\end{array}$ & $\begin{array}{l}3.7^{*} \pm 1.5 \\
(80 \%)\end{array}$ & $\begin{array}{l}16.4^{*} \pm 7.4 \\
(62 \%)\end{array}$ & $\begin{array}{l}14.3^{*} \pm 5.9 \\
(75 \%)\end{array}$ \\
\hline 12 months & $\begin{array}{l}4.3^{*} \pm 1.8 \\
(63 \%)\end{array}$ & $\begin{array}{l}3.8^{*} \pm 1.6 \\
(72 \%)\end{array}$ & $\begin{array}{l}16.4^{*} \pm 7.6 \\
(56 \%)\end{array}$ & $\begin{array}{l}14.5^{*} \pm 6.1 \\
(72 \%)\end{array}$ \\
\hline 18 months & $\begin{array}{l}4.4^{*} \pm 1.9 \\
(60 \%)\end{array}$ & $\begin{array}{l}3.9 * \pm 1.9 \\
(68 \%)\end{array}$ & $\begin{array}{l}16.5^{*} \pm 7.7 \\
(56 \%)\end{array}$ & $\begin{array}{l}14.5^{*} \pm 6.3 \\
(67 \%)\end{array}$ \\
\hline 24 months & $\begin{array}{l}4.4^{*} \pm 1.9 \\
(57 \%)\end{array}$ & $\begin{array}{l}4.0 * \pm 1.7 \\
(65 \%)\end{array}$ & $\begin{array}{l}16.5^{*} \pm 7.7 \\
(56 \%)\end{array}$ & $\begin{array}{l}14.9 * \pm 6.4 \\
(63 \%)\end{array}$ \\
\hline Group difference & \multicolumn{2}{|l|}{0.525} & \multicolumn{2}{|l|}{0.209} \\
\hline Time difference & \multicolumn{2}{|l|}{0.001} & \multicolumn{2}{|l|}{0.001} \\
\hline Group by time interaction & \multicolumn{2}{|l|}{0.104} & \multicolumn{2}{|l|}{0.162} \\
\hline
\end{tabular}

Notes: A lower value indicates better condition; *Significant difference with baseline values within the group $(P<0.05)$; Numbers in parentheses illustrate proportion with significant pain relief $(\geq 50 \%)$ from baseline.

axial low back pain of presumably discogenic origin utilizing fluoroscopic epidural injections. In general, the studies have been criticized for their designs and their inability to confirm the injection of the injectate without using fluoroscopy. In addition, systematic reviews have also faced criticism for their methodology and inclusion of inappropriate studies leading to inaccurate conclusions. ${ }^{24,40,44,45,63,64,74-77}$ Even the recent study published with a placebo design for caudal epidural injections in evaluating the role in disc herniation ${ }^{62}$ was met with significant criticism. ${ }^{78,79}$ Only one study, by Ghahreman et al, ${ }^{80}$ which had a proper placebo-controlled design, has showed no significant effect with sodium chloride solution when injected into an inactive structure. Instead of fluoroscopy, Iverson et al ${ }^{62}$ utilized ultrasound and showed negative results, and their study has been criticized for flaws related to design, conduct, patient selection, and interpretation of results. In an editorial by Cohen $^{81}$ in response to the Iverson el $\mathrm{al}^{62}$ study, Cohen concluded that while epidural injections provide only modest improvement in carefully selected patients, they were considered as an effective adjunct when used judiciously. Thus, in the era of comparative effectiveness research, ${ }^{74,75,77,78,82}$ the evidence from comparative effectiveness or active controlled trials, which include the present study, are crucial in clinical interpretation and intervention.

In patients suffering with chronic low back pain, when utilizing controlled diagnostic blocks, the prevalence of pain due to internal disc disruption has been reported to be $39 \%,{ }^{8}$ and primary discogenic pain has been reported in $26 \%{ }^{7}$ when no other cause was suspected. In the absence of disc herniation or radicular pain, facet joint pain has been shown to be

$\square$ Group I 田 Group II

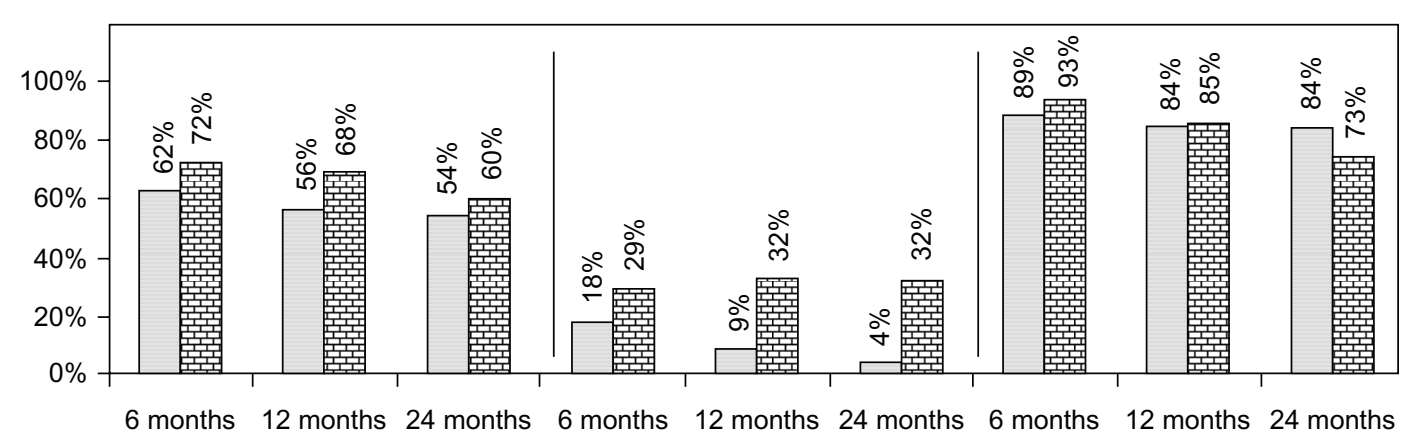

All participants

Failed participants

Successful participants

Figure 2 Proportion of patients with significant reduction in Numeric Rating Score and Oswestry Disability Index ( $\geq 50 \%$ reduction from baseline). 
Table 4 Employment characteristics

\begin{tabular}{|c|c|c|c|c|}
\hline & \multicolumn{2}{|l|}{ Group I } & \multicolumn{2}{|l|}{ Group 2} \\
\hline & Baseline & 24 months & Baseline & 24 months \\
\hline Employed part-time & 4 & 3 & 2 & 4 \\
\hline Employed full-time & 6 & 14 & 10 & 15 \\
\hline Unemployed & 6 & 2 & 8 & 4 \\
\hline Total employed & 10 & 17 & 12 & 19 \\
\hline $\begin{array}{l}\text { Eligible for } \\
\text { employment }\end{array}$ & 16 & 16 & 20 & 20 \\
\hline Housewife & 7 & 4 & 5 & 2 \\
\hline Disabled & 29 & 29 & 33 & 33 \\
\hline Over 65 years of age & 8 & 8 & 2 & 2 \\
\hline $\begin{array}{l}\text { Total number } \\
\text { of patients }\end{array}$ & 60 & 60 & 60 & 60 \\
\hline
\end{tabular}

present in $21 \%-40 \%$ of patients, ${ }^{4,24}$ whereas sacroiliac joint pain has been established in $10 \%-27 \%$ of the population. ${ }^{4,24}$ Thus, discogenic pain may be diagnosed without discography by eliminating all other structures responsible for pain in axial low back pain even when there are no abnormalities noted in the disc and there is no disc herniation or neural compression identified.

This study may be criticized for its lack of a placebo group. However, in recent years, comparative effectiveness research has been considered as pivotal to evidence-based medicine..$^{74,75,77,78,82}$ Even though the current study is limited to a single center, and is an active controlled trial, it is also double-blind and designed to determine whether fluoroscopically directed epidural injections with or without steroids with the usual volumes injected in practice are helpful or not. Consequently, the results of this trial are practical and applicable for interventional pain management settings, highlighting the importance of patient selection and the mode of management with contemporary interventional pain management, with repeat procedures only when the pain returns. Placebo control is a difficult aspect of interventional techniques. A placebo injection into an active structure can

Table 5 Opioid intake (morphine equivalents in $\mathrm{mg}$ )

\begin{tabular}{lll}
\hline $\begin{array}{l}\text { Opioid intake } \\
\text { (morphine equivalence mg) }\end{array}$ & Mean \pm SD \\
\cline { 2 - 3 } & Group I (60) & Group 2 (60) \\
\hline Baseline & $34.5 \pm 33.7$ & $36.2 \pm 19.8$ \\
3 months & $28.7 \pm 27.1$ & $29.9 \pm 19.9$ \\
6 months & $31.5 \pm 38.4$ & $31.0 \pm 19.9$ \\
I2 months & $31.5 \pm 38.4$ & $30.0 \pm 19.9$ \\
I8 months & $31.0 \pm 38.4$ & $29.8 \pm 20.3$ \\
24 months & $31.0 \pm 38.4$ & $29.8 \pm 20.3$ \\
Group difference & 0.453 & \\
Time difference & 0.165 & \\
Group by time interaction & 0.959 & \\
\hline
\end{tabular}

Table 6 Characteristics of changes in weight

\begin{tabular}{llll}
\hline Weight (Ibs) & \multicolumn{2}{l}{ Mean \pm SD } & P value \\
\cline { 2 - 3 } & $\begin{array}{l}\text { Group I } \\
(\mathbf{n}=\mathbf{6 0})\end{array}$ & $\begin{array}{l}\text { Group 2 } \\
(\mathbf{n}=\mathbf{6 0})\end{array}$ & \\
\hline Weight at beginning & $189.5 \pm 59.6$ & $177.1 \pm 42.5$ & $0.19 \mid$ \\
Weight at 24 months & $187.0 \pm 58.1$ & $177.1 \pm 43.5$ & 0.290 \\
Change & $-2.5 \pm 13.6$ & $0 \pm 10.9$ & 0.273 \\
Lost weight & $45 \%(27)$ & $47 \%(28)$ & $0.16 \mathrm{I}$ \\
No change & $20 \%(12)$ & $8 \%(5)$ & \\
Gained weight & $35 \%(21)$ & $45 \%(27)$ & \\
\hline
\end{tabular}

Abbreviation: SD, standard deviation.

lead to various types of effects, including a nocebo effect. ${ }^{83-90}$ Further, misguided attempts to classify local anesthetic injections as placebo also have no basis, considering the mechanism of action of local anesthetics and steroids and recent publications indicating significant effectiveness for local anesthetic injections, similar to steroids. ${ }^{24,38,46,48-57,69-71,91-95}$

The results of the present study describe participants in a private interventional pain management practice setting. Consequently, the results are not applicable to the general population unless the same methodology is utilized with regard to the diagnosis and therapy. Further, the generalizability of the findings of this study might only be feasible in studies utilizing larger populations in multiple settings.

Overall, the evidence in this report demonstrates caudal epidural injections in participants negative for lumbar facet joint pain, without disc herniation or radiculitis, may be treated with caudal epidural injections with or without steroids, providing approximately 12 weeks of relief with each procedure and requiring 3-4 treatments per year and six treatments per 2 years.

\section{Conclusion}

The assessment of the 2-year results of this randomized, double-blind, controlled trial of caudal epidural injections in chronic function-limiting low back pain without facet joint pain, disc herniation, and/or radiculitis, demonstrated effectiveness in $84 \%$ of participants with local anesthetic only and $73 \%$ of participants with local anesthetic and steroids, providing significant pain relief and improvement in functional status in the successful groups at 24 months.

\section{Disclosure}

None of the authors have any competing interests in this work.

\section{References}

1. Peng B, Wu W, Hou S, Li P, Zhang C, Yang Y. The pathogenesis of discogenic low back pain. J Bone Joint Surg Br. 2005;87(1):62-67. 
2. Rhyne AL, Smith SE, Wood KE, Darden BV. Outcome of unoperated discogram-positive low back pain. Spine (Phila Pa 1976). 1995;20(18): 1997-2000.

3. Mooney V. Presidential address. International Society for the Study of the Lumbar Spine. Dallas, 1986. Where is the pain coming from? Spine (Phila Pa 1976). 1987;12(8):754-759.

4. Manchikanti L, Boswell MV, Singh V, et al. Comprehensive review of neurophysiologic basis and diagnostic interventions in managing chronic spinal pain. Pain Physician. 2009;12(4):E71-E120.

5. Manchikanti L, Glaser S, Wolfer L, Derby R, Cohen SP. Systematic review of lumbar discography as a diagnostic test for chronic low back pain. Pain Physician. 2009;12(3):541-559.

6. Hancock MJ, Maher CG, Latimer J, et al. Systematic review of tests to identify the disc, SIJ or facet joint as the source of low back pain. Eur Spine J. 2007;16(10):1539-1550.

7. Manchikanti L, Singh V, Pampati V, et al. Evaluation of the relative contributions of various structures in chronic low back pain. Pain Physician. 2001;4(4):308-316.

8. Schwarzer AC, Aprill CN, Derby R, Fortin J, Kine G, Bogduk N. The prevalence and clinical features of internal disc disruption in patients with chronic low back pain. Spine (Phila Pa 1976). 1995;20(17): $1878-1883$.

9. Wolfer L, Derby R, Lee JE, Lee SH. Systematic review of lumbar provocation discography in asymptomatic subjects with a meta-analysis of false-positive rates. Pain Physician. 2008;11(4):513-538.

10. Carragee EJ, Lincoln TF, Parmar VS, Alamin T. A gold standard evaluation of the "discogenic pain" diagnosis as determined by provocative discography. Spine (Phila Pa 1976). 2006;31(18):2115-2123.

11. Carragee EJ, Tanner CM, Yang B, Brito JL, Truong T. False-positive findings on lumbar discography. Reliability of subjective concordance assessment during provocative disc injection. Spine (Phila Pa 1976). 1999;24(23):2542-2547.

12. Carragee EJ, Barcohana B, Alamin T, van den Haak E. Prospective controlled study of the development of lower back pain in previously asymptomatic subjects undergoing experimental discography. Spine (Phila Pa 1976). 2004;29(10):1112-1117.

13. Derby R, Kim BJ, Lee SH, Chen Y, Seo KS, Aprill C. Comparison of discographic findings in asymptomatic subject discs and the negative discs of chronic LBP patients: can discography distinguish asymptomatic discs among morphologically abnormal discs? Spine $J$. 2005;5(4):389-394.

14. Derby R, Lee SH, Kim BJ, Chen Y, Aprill C, Bogduk N. Pressurecontrolled lumbar discography in volunteers without low back symptoms. Pain Med. 2005;6(3):213-221.

15. Mixter WJ, Barr JS. Rupture of the intervertebral disc with involvement of the spinal canal. N Engl J Med. 1934;211:210-215.

16. Mixter WJ, Ayers JB. Herniation or rupture of the intervertebral disc into the spinal canal. N Engl J Med. 1935;213:385-395.

17. Konstantinou K, Dunn KM. Sciatica: review of epidemiological studies and prevalence estimates. Spine (Phila Pa 1976). 2008;33(22): 2464-2472.

18. Savettieri G, Salemi G, Rocca WA, et al; for Sicilian Neuro-Epidemiologic Study (SNES) Group. Prevalence of lumbosacral radiculopathy in two Sicilian municipalities. Acta Neurol Scand. 1996;93(6):464-469.

19. Kang JD, Stefanovic-Racic M, McIntyre LA, Georgescu HI, Evans CH. Toward a biochemical understanding of human intervertebral disc degeneration and herniation. Contributions of nitric oxide, interleukins, prostaglandin E2, and matrix metalloproteinases. Spine (Phila Pa 1976). 1997;22(10):1065-1073.

20. McCarron RF, Wimpee MW, Hudkins PG, Laros GS. The inflammatory effects of nucleus pulposus: a possible element in the pathogenesis of low back pain. Spine (Phila Pa 1976). 1987;12(8):760-764.

21. O'Neill CW, Kurgansky ME, Derby R, Ryan DP. Disc stimulation and patterns of referred pain. Spine (Phila Pa 1976). 2002;27(24): 2776-2781.

22. Crock HV. Isolated lumbar disc resorption as a cause of nerve root canal stenosis. Clin Orthop. 1976;115:109-115.
23. Holm S, Holm AK, Ekstrom L, Karladani A, Hansson T. Experimental disc degeneration due to endplate injury. J Spinal Disord Tech. 2004; 17(1):64-71.

24. Manchikanti L, Boswell MV, Singh V, et al. Comprehensive evidencebased guidelines for interventional techniques in the management of chronic spinal pain. Pain Physician. 2009;12(4):699-802.

25. Aoki Y, Ohtori S, Ino $\mathrm{H}$, et al. Disc inflammation potentially promotes axonal regeneration of dorsal root ganglion neurons innervating lumbar intervertebral disc in rats. Spine (Phila Pa 1976). 2004;29(23): 2621-2626.

26. Hayashi Y, Ohtori S, Yamashita M, et al. Direct single injection of p38 mitogen-activated protein kinase inhibitor does not affect calcitonin gene-related peptide expression in dorsal root ganglion neurons innervating punctured discs in rats. Spine (Phila Pa 1976). 2009;24(26): 2295-2299.

27. Miyagi $M$, Ishikawa $T$, Orita $S$, et al. Disk injury in rats produces persistent increases in pain-related neuropeptides in dorsal root ganglia and spinal cord glia but only transient increases in inflammatory mediators: pathomechanism of chronic diskogenic low back pain. Spine (Phila Pa 1976). 2011;36(26):2260-2266.

28. Helm S 2nd, Deer TR, Manchikanti L, et al. Effectiveness of thermal annular procedures in treating discogenic low back pain. Pain Physician. 2012;15(3):E279-E304.

29. Blondel B, Tropiano P, Guadart J, Huang RC, Marnay T. Clinical results of lumbar total disc arthroplasty in accordance with Modic signs, with a 2-year-minimum follow-up. Spine (Phila Pa 1976). 2011;36(26): 2309-2315.

30. Oh WS, Shim JC. A randomized controlled trial of radiofrequency denervation of the ramus communicans nerve for chronic discogenic low back pain. Clin J Pain. 2004;20(1):55-60.

31. Tsou PM, Yeung CA, Yeung AT. Posterolateral transforaminal selective endoscopic discectomy and thermal annuloplasty for chronic lumbar discogenic pain: a minimal access visualized intradiscal surgical procedure. Spine J. 2004;4(5):564-573.

32. Peng B, Pang X, Zhao C, Song X. A randomized placebo-controlled trial of intradiscal methylene blue injection for the treatment of chronic discogenic low back pain. Pain. 2010;149(1):124-129.

33. Ohtori S, Kinoshita T, Yamashita M, et al. Results of surgery for discogenic low back pain: a randomized study using discography versus discoblock for diagnosis. Spine (Phila Pa 1976). 2009;34(13): $1345-1348$.

34. Ohtori S, Koshi T, Yamashita M, et al. Surgical versus nonsurgical treatment of selected patients with discogenic low back pain: a small-sized randomized trial. Spine (Phila Pa 1976). 2011;36(5): 347-354.

35. Madan S, Gundanna M, Harley JM, Boeree NR, Sampson M. Does provocative discography screening of discogenic back pain improve surgical outcome? J Spinal Disord Tech. 2002;15(3):245-251.

36. Maghout-Juratli S, Franklin GM, Mirza SK, Wickizer TM, FultonKohoe D. Lumbar fusion outcomes in Washington state workers' compensation. Spine (Phila Pa 1976). 2006;31(23):2715-2723.

37. Manchikanti L, Cash KA, McManus CD, Pampati V, Smith HS. One year results of a randomized, double-blind, active controlled trial of fluoroscopic caudal epidural injections with or without steroids in managing chronic discogenic low back pain without disc herniation or radiculitis. Pain Physician. 2011;14(1):25-36.

38. Manchikanti L, Cash KA, McManus CD, Pampati V, Benyamin RM. Preliminary results of a randomized, double-blind, controlled trial of fluoroscopic lumbar interlaminar epidural injections in managing chronic lumbar discogenic pain without disc herniation or radiculitis. Pain Physician. 2010;13(4):E279-E292.

39. Vallejo R, Manuel Zevallos L, Lowe J, Benyamin R. Is spinal cord stimulation an effective treatment option for discogenic pain? Pain Pract. 2012;12(3):194-201.

40. Chou R, Huffman L. Guideline for the Evaluation and Management of Low Back Pain: Evidence Review. American Pain Society: Glenview, IL; 2009. 
41. Manchikanti L, Pampati V, Boswell MV, Smith HS, Hirsch JA. Analysis of the growth of epidural injections and costs in the Medicare population: a comparative evaluation of 1997, 2002, and 2006 data. Pain Physician. 2010;13(3):199-212.

42. Friedly J, Leighton C, Deyo R. Increases in lumbosacral injections in the Medicare population: 1994 to 2001. Spine (Phila Pa 1976). 2007;32:1754-1760.

43. Abbott ZI, Nair KV, Allen RR, Akuthota VR. Utilization characteristics of spinal interventions. Spine J. 2012;12(1):35-43.

44. Manchikanti L, Datta S, Derby R, Wolfer LR, Benyamin RM, Hirsch JA. A critical review of the American Pain Society clinical practice guidelines for interventional techniques: Part 1. Diagnostic interventions. Pain Physician. 2010;13(3):E141-E174.

45. Manchikanti L, Datta S, Gupta S, et al. A critical review of the American Pain Society clinical practice guidelines for interventional techniques: Part 2. Therapeutic interventions. Pain Physician. 2010; 13(4):E215-E264.

46. Manchikanti L, Singh V, Rivera JJ, et al. Effectiveness of caudal epidural injections in discogram positive and negative chronic low back pain. Pain Physician. 2002;5(1):18-29.

47. Butterman GR. The effect of spinal steroid injections for degenerative disc disease. Spine J. 2004;4(5):495-505.

48. Manchikanti L, Cash KA, Pampati V, Wargo BW, Malla Y. Cervical epidural injections in chronic discogenic neck pain without disc herniation or radiculitis: Preliminary results of a randomized, double-blind, controlled trial. Pain Physician. 2010;13(4):E265-E278.

49. Manchikanti L, Cash KA, McManus CD, Pampati V, Benyamin RM. A preliminary report of a randomized double-blind, active controlled trial of fluoroscopic thoracic interlaminar epidural injections in managing chronic thoracic pain. Pain Physician. 2010;13(6):E357-E369.

50. Manchikanti L, Cash KA, Pampati V, Malla Y. Fluoroscopic cervical epidural injections in chronic axial or discogenic neck pain without disc herniation or facet joint pain or radiculitis. J Pain Res. 2012; In press.

51. Manchikanti L, Cash KA, McManus CD, Pampati V, Benyamin R. Fluoroscopic lumbar interlaminar epidural injections in managing chronic lumbar axial or discogenic pain. J Pain Res. 2012; In press.

52. Manchikanti L, Singh V, Cash KA, Pampati V, Datta S. Management of pain of post lumbar surgery syndrome: one-year results of a randomized, double-blind, active controlled trial of fluoroscopic caudal epidural injections. Pain Physician. 2010;13(6):509-521.

53. Manchikanti L, Cash KA, McManus CD, Pampati V, Fellows B. Fluoroscopic caudal epidural injections with or without steroid in managing pain of lumbar spinal stenosis: one year results of randomized, double-blind, active-controlled trial. J Spinal Disord. 2012;25(4): 226-234.

54. Manchikanti L, Singh V, Falco FJE, Cash KA, Pampati V. Evaluation of the effectiveness of lumbar interlaminar epidural injections in managing chronic pain of lumbar disc herniation or radiculitis: a randomized, double-blind, controlled trial. Pain Physician. 2010;13(4):343-355.

55. ManchikantiL, Cash KA, McManus CD, Damron KS, PampatiV,Falco FJE. Lumbar interlaminar epidural injections in central spinal stenosis: preliminary results of a randomized, double-blind, active control trial Pain Physician. 2012;15(1):51-63.

56. Manchikanti L, Cash KA, Pampati V, Wargo BW, Malla Y. The effectiveness of fluoroscopic cervical interlaminar epidural injections in managing chronic cervical disc herniation and radiculitis: preliminary results of a randomized, double-blind, controlled trial. Pain Physician. 2010;13(3):223-236

57. Manchikanti L, Malla Y, Cash KA, McManus CD, Pampati V. Fluoroscopic epidural injections in cervical spinal stenosis: preliminary results of a randomized, double-blind, active control trial. Pain Physician. 2012;15(1):E59-E70.

58. Dashfield AK, Taylor MB, Cleaver JS, Farrow D. Comparison of caudal steroid epidural with targeted steroid placement during spinal endoscopy for chronic sciatica: a prospective, randomized, double-blind trial. $\mathrm{Br}$ J Anaesth. 2005;94(4):514-519.
59. Gharibo CG, Varlotta GP, Rhame EE, Liu EC, Bendo JA, Perloff MD Interlaminar versus transforaminal epidural steroids for the treatment of subacute lumbar radicular pain: a randomized, blinded, prospective outcome study. Pain Physician. 2011;14(6):499-511.

60. Sayegh FE, Kenanidis EI, Papavasiliou KA, Potoupnis ME, Kirkos JM, Kapetanos GA. Efficacy of steroid and nonsteroid caudal epidural injections for low back pain and sciatica: a prospective, randomized, double-blind clinical trial. Spine (Phila Pa 1976). 2009;34(14): 1441-1447.

61. Ackerman WE 3rd, Ahmad M. The efficacy of lumbar epidural steroid injections in patients with lumbar disc herniations. Anesth Analg. 2007;104(5):1217-1222.

62. Iversen T, Solberg TK, Romner B, et al. Effect of caudal epidural steroid or saline injection in chronic lumbar radiculopathy: multicentre, blinded, randomised controlled trial. BMJ. 2011;343:d5278.

63. Manchikanti L, Singh V, Boswell MV. Interventional pain management at crossroads: the perfect storm brewing for a new decade of challenges. Pain Physician. 2010;13(2):E111-E140.

64. Benyamin RM, Datta S, Falco FJ. A perfect storm in interventional pain management: regulated, but unbalanced. Pain Physician. 2010;13(2): $109-116$.

65. Manchikanti L, Cash KA, McManus CD, Pampati V, Smith HS Preliminary results of randomized, equivalence trial of fluoroscopic caudal epidural injections in managing chronic low back pain: Part 1. Discogenic pain without disc herniation or radiculitis. Pain Physician 2008;11(6):785-800.

66. Altman DG, Schulz KF, Moher D, et al. The revised CONSORT statement for reporting randomized trials: explanation and elaboration. Ann Intern Med. 2001;134(8):663-694.

67. Manchukonda R, Manchikanti KN, Cash KA, Pampati V, Manchikanti L. Facet joint pain in chronic spinal pain: an evaluation of prevalence and false-positive rate of diagnostic blocks. J Spinal Disord Tech. 2007; 20(7):539-545.

68. Manchikanti L, Benyamin RM, Helm S, Hirsch JA. Evidence-based medicine, systematic reviews, and guidelines in interventional pain management. Part 3: systematic reviews and meta-analyses of randomized trials. Pain Physician. 2009;12(1):35-72.

69. Manchikanti L, Singh V, Falco FJ, Cash KA, Pampati V. Evaluation of lumbar facet joint nerve blocks in managing chronic low back pain: a randomized, double-blind, controlled trial with a 2-year follow-up. Int J Med Sci. 2010;7(3):124-135.

70. Manchikanti L, Singh V, Falco FJE, Cash KA, Fellows B. Comparative outcomes of a 2-year follow-up of cervical medial branch blocks in management of chronic neck pain: a randomized, double-blind controlled trial. Pain Physician. 2010;13(5):437-450.

71. Manchikanti L, Singh V, Falco FJE, Cash KA, Pampati V, Fellows B. Comparative effectiveness of a one-year follow-up of thoracic medial branch blocks in management of chronic thoracic pain: a randomized, double-blind active controlled trial. Pain Physician. 2010;13(6): 535-548.

72. Pereira J, Lawlor P, Vigano A, Dorgan M, Bruera E. Equianalgesic dose ratios for opioids. A critical review and proposals for long-term dosing. J Pain Symptom Manage. 2001;22(2):672-687.

73. Browner WS, Newman TB, Cummings SR, Hulley SB. Estimating sample size and power. In: Hulley SB, Cummins SR, Brownder WS, et al, editors. Designing Clinical Research: An Epidemiologic Approach. 2nd ed. Philadelphia, PA: Lippincott, Williams \& Wilkins; 2001.

74. Manchikanti L, Falco FJE, Boswell MV, Hirsch JA. Facts, fallacies, and politics of comparative effectiveness research: Part 1. Basic considerations. Pain Physician. 2010;13(1):E23-E54.

75. Manchikanti L, Falco FJE, Boswell MV, Hirsch JA. Facts, fallacies, and politics of comparative effectiveness research: Part 2. Implications for interventional pain management. Pain Physician. 2010;13(1): E55-E79.

76. Chou R, Atlas SJ, Loeser JD, Rosenquist RW, Stanos SP. Guideline warfare over interventional therapies for low back pain: can we raise the level of discourse? J Pain. 2011;12(8):833-839. 
77. Manchikanti L, Benyamin RM, Falco FJE, Caraway DL, Datta S, Hirsch JA. Guidelines warfare over interventional techniques: is there a lack of discourse or straw man? Pain Physician. 2012;15(1):E1-E26.

78. Gupta S, Ward S, Munglani R, Sharma M. Letter to the Editor. Re: Iversen T, Solberg TK, Romner B, et al. Effect of caudal epidural steroid or saline injection in chronic lumbar radiculopathy: multicentre, blinded, randomised controlled trial. BMJ. 2011;343:d5278. Careful patient selection, fluoroscopy and contrast injection are needed for effective spinal injections. Published online September 26, 2011. Author's reply published online September 19, 2011.

79. Norman. Letter to the Editor. Re: Iversen T, Solberg TK, Romner B, et al. Effect of caudal epidural steroid or saline injection in chronic lumbar radiculopathy: multicentre, blinded, randomised controlled trial. BMJ. 2011;343:d5278. The effect of caudal epidural in chronic lumbar radiculopathy remains unclear. Published online September 23, 2011. Author's reply published online September 24, 2011.

80. Ghahreman A, Ferch R, Bogduk N. The efficacy of transforaminal injection of steroids for the treatment of lumbar radicular pain. Pain Med. 2010;11(8):1149-1168.

81. Cohen SP. Epidural steroid injections for low back pain. BMJ. 2011; 343:d5310.

82. Manchikanti L, Falco FJ, Benyamin RM, Helm S 2nd, Parr AT, Hirsch JA. The impact of comparative effectiveness research on interventional pain management: evolution from Medicare modernization act to patient protection and affordable care act and the patient-centered outcomes research institute. Pain Physician. 2011;14(3):E249-E282.

83. Carette S, Leclaire R, Marcoux S, et al. Epidural corticosteroid injections for sciatica due to herniated nucleus pulposus. $N$ Engl J Med. 1997; 336(23):1634-1640.

84. Karppinen J, Malmivaara A, Kurunlahti M, et al. Periradicular infiltration for sciatica: a randomized controlled trial. Spine (Phila Pa 1976). 2001;26(9):1059-1067.

85. Manchikanti L, Giordano J, Fellows B, Hirsch JA. Placebo and nocebo in interventional pain management: a friend or a foe - or simply foes? Pain Physician. 2011;14(2):E157-E175.
86. Manchikanti L, Pampati V, Damron KS. The role of placebo and nocebo effects of perioperative administration of sedatives and opioids in interventional pain management. Pain Physician. 2005;8(4):349-355.

87. Indahl A, Kaigle AM, Reikeräs O, Holm SH. Interaction between the porcine lumbar intervertebral disc, zygapophysial joints, and paraspinal muscles. Spine (Phila Pa 1976). 1997;22(24):2834-2840.

88. Indahl A, Kaigle A, Reikerås O, Holm S. Electromyographic response of the porcine multifidus musculature after nerve stimulation. Spine (Phila Pa 1976). 1995;20(24):2652-2658.

89. Pham Dang C, Lelong A, Guilley J, et al. Effect on neurostimulation of injectates used for perineural space expansion before placement of a stimulating catheter: normal saline versus dextrose 5\% in water. Reg Anesth Pain Med. 2009;34(5):398-403.

90. Tsui BC, Kropelin B, Ganapathy S, Finucane B. Dextrose 5\% in water: fluid medium for maintaining electrical stimulation of peripheral nerves during stimulating catheter placement. Acta Anaesthesiol Scand. 2005;49(10):1562-1565.

91. Smuck M, Levin JH. Comment on: Manchikanti L, Singh V, Falco FJ, et al. Cervical medial branch blocks for chronic cervical facet joint pain: a randomized, double-blind, controlled trial with one-year follow-up. Spine. 2008;33(17):1813-1820.

92. Pasqualucci A, Varrassi G, Braschi A, et al. Epidural local anesthetic plus corticosteroid for the treatment of cervical brachial radicular pain: single injection versus continuous infusion. Clin J Pain. 2007;23(7): 551-557.

93. Tachihara H, Sekiguchi M, Kikuchi S, Konno S. Do corticosteroids produce additional benefit in nerve root infiltration for lumbar disc herniation? Spine (Phila Pa 1976). 2008;33(7):743-747.

94. Sato C, Sakai A, Ikeda Y, Suzuki H, Sakamoto A. The prolonged analgesic effect of epidural ropivacaine in a rat model of neuropathic pain. Anesth Analg. 2008;106(1):313-320.

95. Hayashi N, Weinstein JN, Meller ST, Lee HM, Spratt KF, Gebhart GF. The effect of epidural injection of betamethasone or bupivacaine in a rat model of lumbar radiculopathy. Spine (Phila Pa 1976). 1998;23(8): 877-885.
Journal of Pain Research

\section{Publish your work in this journal}

The Journal of Pain Research is an international, peer-reviewed, open access, online journal that welcomes laboratory and clinical findings in the fields of pain research and the prevention and management of pain. Original research, reviews, symposium reports, hypothesis formation and commentaries are all considered for publication.

\section{Dovepress}

The manuscript management system is completely online and includes a very quick and fair peer-review system, which is all easy to use. Visit http://www.dovepress.com/testimonials.php to read real quotes from published authors. 